\title{
Wpływ pandemii COVID-19 na badania społeczne dotyczące starości i starzenia się
}

\section{Anna Urbaniak}

Streszczenie: W związku z wybuchem pandemii COVID-19 badacze społeczni na całym świecie borykają się z bezprecedensowymi ograniczeniami, ponieważ większość z wykorzystywanych przez nich technik gromadzenia danych opiera się na bezpośrednich interakcjach międzyludzkich. W związku z tym wielu badaczy zajmujących się badaniami nad starością i starzeniem się stanęło w obliczu wyzwania dotyczącego tego, w jaki sposób bezpiecznie prowadzić badania empiryczne. Celem tego artykułu jest przedstawienie subiektywnej refleksji nad etycznymi i metodologicznymi aspektami prowadzenia badań społecznych dotyczących starości i starzenia się w czasie trwania pandemii COVID-19. W tym celu identyfikuję czynniki wpływające na badania społeczne w czasie pandemii COVID-19 a następnie przedstawiam pytania, które mogły pojawić się na poszczególnych etapach procesu badawczego w następstwie wybuchu pandemii COVID-19. Omawiając różne strategie przyjmowane przez badaczy konkluduję wskazując na brak uniwersalnych rozwiązań i możliwe długofalowe skutki wpływu pandemii COVID-19 na realizację badań społecznych dotyczących starości i starzenia się.

Słowa kluczowe: osoby starsze; badania społeczne; COVID-19; metodologia; etyka

Kody JEL: $\quad$ I14, I18

\section{Wstęp}

Wybuch pandemii COVID-19 wywarł wpływ na wszystkie obszary życia, wymuszając zmiany w działaniu państw i jednostek (Rozporządzenie Ministra Zdrowia z dnia 13 marca 2020 r.; Tisdell, 2020). Wiele krajów podjęło decyzje o zamknięciu granic i namawiało obywateli do ograniczenia swojej obecności w przestrzeni publicznej. Instytucje edukacyjne zmuszone były realizować, przynajmniej część swojej działalności, w sposób zdalny. Wiele projektów badawczych zostało zawieszonych, a część instytucji finansujących rozwój nauki wstrzymało ogłaszanie nowych konkursów naukowych lub zdecydowało się przeznaczyć środki wyłącznie na badania związane z COVID-19 (Omary et al., 2020; Błocki, 2020).

Pandemia w bezprecedensowy sposób przedefiniowała sposób myślenia o prowadzeniu badań z osobami starszymi, które definiowane były w dyskursie medialnym jako homogeniczna populacja, w której ryzyko zakażenia i śmierci było najwyższe (Li et al., 2020). Przyczyniło się to do powstania wielu publikacji podnoszących znaczenie ageizmu w dyskusjach medialnych i politycznych (Ayalon et al., 2020; Previtali et al., 2020), a także w rozumieniu tego jak należy definiować grupy ryzyka (Rahman \& Jahan, 2020) w świetle trwającej pandemii. Publi- 
kacje wskazują, że osoby starsze prezentowane były jako homogeniczna grupa, którą należy chronić, odseparować od innych, a w bardziej ekstremalnych wypadkach wyłączyć z systemu ochrony zdrowia i zaoszczędzone w ten sposób zasoby przeznaczyć na leczenie osób młodszych (Truog et al. 2020). Ten sposób przedstawiania osób starszych wywołał sprzeciw wielu organizacji badawczych, które skupiają swoją działalność na badaniu starości i starzenia się (np. BSG, 2020; ICSG 2020). W Polsce sytuacja osób starszych w czasie pandemii COVID-19 przez niektórych określona została lustrem odbijającym bolączki i słabości społeczne (Augustyniak et al. 2020).

W naukach społecznych wiele uwagi poświęcono temu, w jaki sposób można realizować badania w czasach pandemii (Lupton 2020; Jowett, 2020) jednak w niewystarczający sposób skupiono się na badaniach z osobami starszymi, co w kontekście przedstawionego wcześniej dyskursu wydaje się szczególnie interesujące i potrzebne. Z tego względu, w tym artykule przedstawiam metodologiczną refleksję nad tym, jak w czasach pandemii można prowadzić badania empiryczne nad starzeniem się. Po pierwsze, identyfikuję czynniki wpływające na badania społeczne w czasie pandemii. Następnie analizuję wpływ pandemii COVID-19 na badania dotyczące starości i starzenia przez pryzmat pytań, które mogły pojawić się na poszczególnych etapach procesu badawczego w następstwie jej wybuchu. W ostatniej części artykułu wskazuję możliwe długofalowe skutki wpływu pandemii COVID-19 na realizację badań społecznych dotyczących starości i starzenia się.

\section{Czynniki wpływające na badania społeczne w czasach pandemii COVID-19}

Aby lepiej zrozumieć w jaki sposób pandemia COVID-19 wpływa na realizowanie badań z osobami starszymi i na ich temat, proponuję w pierwszej kolejności przeanalizować czynniki, które wpływają na sposób realizacji badań społecznych w ogóle. Na potrzeby niniejszych rozważań traktować będę wybuch pandemii COVID-19 jako nagłe wydarzenie, które zaburza znany i przyjęty sposób postępowania w realizowaniu badań społecznych. Czynniki wpływające na badania społeczne w czasach pandemii COVID-19 proponuję podzielić na trzy grupy: (1) czynniki wynikające z natury samej pandemii, (2) czynniki wynikające ze sposobów zarządzania pandemią oraz (3) czynniki wynikające ze społecznego postrzegania pandemii. W pierwszej grupie czynników należy wymienić: płynność sytuacji i brak pewności dotyczącej przyszłości. W drugiej: sposoby definiowania grup ryzyka, wprowadzany rygor sanitarny i środki zapobiegające zarażeniom. Do trzeciej grupy zaliczyć należy jednostkowe i grupowe wyobrażenia dotyczące pandemii.

Rysunek 1 w schematyczny sposób przedstawia omówione czynniki, zależności pomiędzy nimi i ich wpływ na badania społeczne. Przedstawione czynniki są powiązane i oddziałują wielowymiarowo na wszystkie etapy procesu badawczego, niezależnie od obszaru tematycznego realizowanych badań społecznych. Ich wpływ przekłada się na: brak możliwości opracowania uniwersalnych zasad i wytycznych dotyczących postępowania w procesie badawczym, sposób realizacji poszczególnych etapów procesu badawczego oraz stosunek do badań społecznych. 

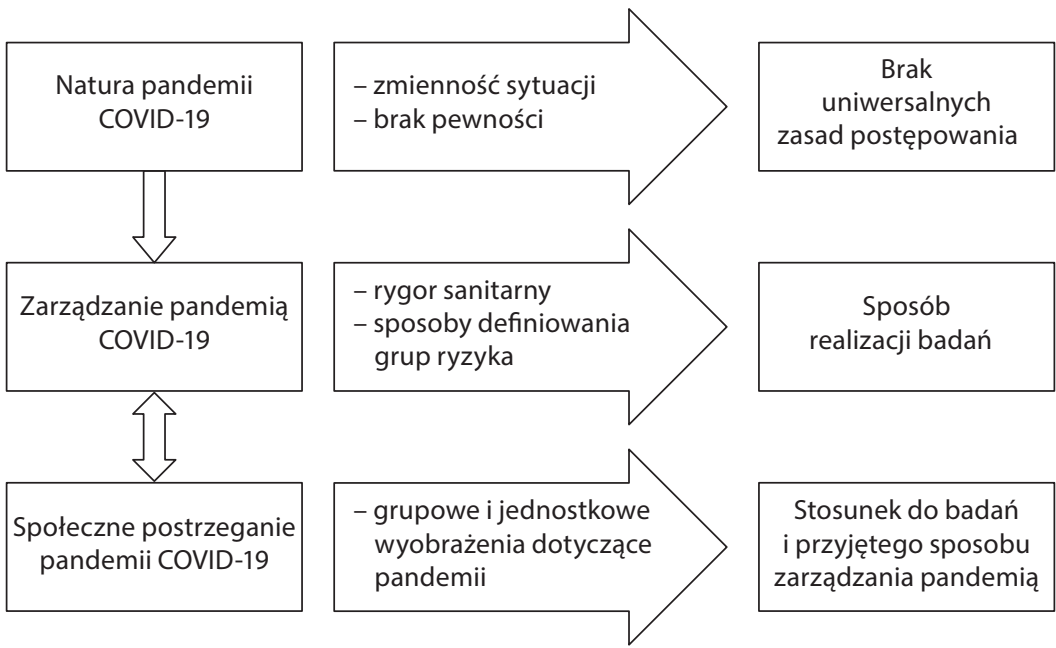

Stosunek do badań i przyjętego sposobu zarządzania pandemią

\section{Rysunek 1. Czynniki wpływające na badania społeczne w czasach pandemii COVID-19}

Źródło: opracowanie własne

\section{Wpływ pandemii COVID-19 na badania dotyczące starości i starzenia się}

W tym opracowaniu uwaga skoncentrowana zostanie na badaniach społecznych dotyczących starości i starzenia się, które nie opierają się na danych zastanych. Wpływ pandemii COVID-19 na badania dotyczące starości i starzenia się proponuję analizować przez pryzmat pytań, które mogły pojawić się na poszczególnych etapach procesu badawczego w następstwie wybuchu pandemii COVID-19.

\section{Projekty badawcze w fazie projektowania}

W momencie wybuchu pandemii COVID-19 (nie tylko w obszarze nauk społecznych) część środków została zamrożona, bądź przesunięta z innych obszarów badawczych na badania dotyczące bezpośrednio pandemii COVID-19 (Błocki, 2020). Wielu badaczy stanęło przed pytaniami natury etycznej i praktycznej: czy, w świetle wybuchu pandemii, temat badawczy, dotyczący starości i starzenia się, który chcę podjąć jest ważny i aktualny? Czy temat badawczy, dotyczący starości i starzenia się, który chcę podjęć jest możliwy do realizacji w warunkach pandemii COVID-19? Czy planując badania dotyczące starości i starzenia się koncentrować się na zagadnieniach, które w obecnej sytuacji mają największe szanse na otrzymanie finansowania?

Badania, które w momencie wybuchu pandemii były w fazie projektowania miały możliwość najbardziej elastycznej reakcji na sytuację. Oznacza to, że po podjęciu decyzji dotyczących zasadności realizowania danego tematu badawczego w warunkach pandemii COVID-19 (kwestie etyczne), kolejne etapy procesu badawczego (w tym stosowana metodologia) mogły być projektowane przez badaczy z uwzględnieniem istniejących ograniczeń wynikających zarówno z natury pandemii COVID-19, sposobów zarządzania nią jak i społecznego jej postrzegania. Jest to szczególnie istotne w przypadku projektowania metodologii badań (wykorzystanie technik gromadzenia danych niewymagających bezpośrednich interakcji) czy budżetu projektu (zabezpieczenie środków na materiały ochronne lub wykorzystanie bezpiecznych platform do prowadzenia badań online). W przypadku badań, które w czasie wybuchu pande- 
mii COVID-19 były na etapie projektowania, pytania generowane przez jej wybuch a kluczowe dla kolejnych etapów realizacji projektu badawczego (rekrutacja starszych uczestników, techniki gromadzenia danych empirycznych, analiza danych i upowszechnianie wyników) mogły być zadane a priori. Dodatkowo należy zaznaczyć, że wybuch pandemii COVID-19 dostarczył okazji do poszerzenia pola badawczego o kwestie wpływu pandemii na doświadczanie różnych aspektów starości. To mogło przyczynić się do zainspirowania nowych wątków badawczych istotnych także z perspektywy ekonomii społecznej (Perek - Białas, 2013, Hausner, 2007).

\section{Projekty $w$ fazie rekrutacji uczestników}

Badacze realizujący projekty, które w momencie wybuchu pandemii COVID-19 były w fazie rekrutacji uczestników stanęli przed pytaniami zarówno natury etycznej jak i metodologicznej: czy etyczne jest kontynuowanie projektu, w którym mają brać udział osoby starsze? W jaki sposób, w nowych warunkach, należy rozumieć świadomą zgodę osoby starszej na udział w badaniu? W jaki sposób ewentualna zmiana sposobu rekrutacji osób starszych wpłynie na uzyskane dane i wyniki realizowanego badania?

W przypadku projektów, które zakładały rekrutację osób starszych dostęp do potencjalnych uczestników został w znaczący sposób ograniczony. Wynikało to zarówno z przyjętego sposobu zarządzania pandemią (ograniczanie bezpośrednich kontaktów społecznych, osoby starsze ujmowane jako grupa ryzyka), jak i społecznego jej postrzegania (osoby starsze jako jednolita grupa wymagająca szczególnej ochrony). Z tego względu niektóre projekty zostały zawieszone, w innych natomiast przyjmowano sposoby działania wynikające ze zmieniającej się sytuacji. Największy wpływ pandemii COVID-19 na rekrutację osób starszych wiąże się z ograniczeniem dostępu do placówek świadczących opiekę długoterminową jak i możliwą niechęcią pracowników tych instytucji do wspierania kontaktu między ich klientami a badaczami. Istniejące opracowania wskazują, że pracownicy takich instytucji często mogą odczuwać potrzebę chronienia swoich klientów (Jacelon, 2007), co w czasach pandemii COVID-19 może się dodatkowo nasilać zarówno ze względu na sposób zarządzania pandemią, jak i społeczne jej postrzeganie.

Dodatkowo część organizacji i instytucji, zorientowanych na wspieranie osób starszych, w związku z przyjętym sposobem zarządzania pandemią COVID-19, ograniczyła lub zawiesiła swoją działalność, co uniemożliwiało prowadzenie rekrutacji z ich udziałem i/lub na ich terenie. Wreszcie same osoby starsze w czasie trwania pandemii mogły być mniej chętne do udziału w projektach badawczych. Z drugiej strony, część osób starszych mogła chętniej zgadzać się na udział w badaniach, przeciwstawiając się w ten sposób ograniczeniom wynikającym z zarządzania pandemią (tj. ograniczenie kontaktów społecznych), jak i ze społecznego postrzegania pandemii (prezentowanie osób starszych jako jednorodnej grupy wymagającej ochrony). Jest to zgodne z opisanymi mechanizmami ochrony poczucia własnej wartości u osób starszych w obliczu negatywnych stereotypów i ageizmu (Weiss i Lang, 2012).

Niezależnie od indywidualnych motywacji osób starszych do uczestnictwa w badaniu, badacz przed procesem gromadzenia danych musi otrzymać od potencjalnych uczestników świadomą i dobrowolną zgodę na udział w badaniu (por. PTS, 2012, punkt 9). Zazwyczaj w badaniach społecznych kwestie dotyczące ryzyka obejmującego stan zdrowia nie były uwzględniane, jednak w czasie pandemii COVID-19 w oczywisty sposób zyskały na znaczeniu. Oznacza to, że badacze musieli w jasny sposób zakomunikować zarówno ryzyko jak i sposoby radzenia sobie z nim (wynikające ze sposobów zarządzania pandemią) i uzyskać od potencjal- 
nych uczestników zgodę na udział w badaniu na zasadach wynikających z przyjętego sposobu zarządzania pandemią.

W przypadkach, gdy badacze decydowali się na zmianę sposobu rekrutacji uczestników konieczne było rozważenie wpływu jaki decyzja taka mogła wywierać na cały projekt badawczy. Przede wszystkim wiązać mogło się to z wykluczeniem pewnych grup osób starszych (np. osoby znajdujące się w placówkach opiekuńczych, osoby nieposiadające telefonów, osoby wykluczone cyfrowo) z udziału w badaniu. To z kolei przekłada się na zmianę struktury próby badawczej i może w znaczący wpływ wykrzywiać uzyskane wyniki (Winship \& Mare, 1992).

\section{Projekty $w$ fazie gromadzenia danych empirycznych}

Badacze, którzy w momencie wybuchu pandemii COVID-19 mieli już za sobą etap rekrutacji uczestników, stawali przed pytaniami natury etycznej, metodologicznej i praktycznej: czy zasadne jest kontynuowanie gromadzenia danych wymagających bezpośredniej interakcji z osobami starszymi? W jaki sposób bezpiecznie gromadzić dane opierające się na bezpośredniej interakcji z osobami starszymi? Jaki wpływ na uzyskane dane i wyniki badań może mieć ewentualna zmiana sposobu gromadzenia danych? W jaki sposób bezpiecznie gromadzić dane opierające się o wykorzystanie technik gromadzenia danych zdalnie (za pośrednictwem poczty, telefony lub platform online)?

W przypadku badań zakładających gromadzenie danych w oparciu o bezpośrednie interakcje z osobami starszymi część badaczy zdecydowała się zawiesić prace badawcze w nadziei na możliwość kontynuowania ich w niezmienionym kształcie po zniesieniu ograniczeń wynikających ze sposobu zarzadzania pandemią COVID-19. Gdy było to możliwe, badacze decydowali się na kontunuowanie gromadzenia danych wymagających bezpośrednich interakcji z osobami starszymi z zachowaniem niezbędnych środków bezpieczeństwa. W takich wypadkach pojawiały się pytania dotyczące odpowiedzialności za bezpieczeństwo zarówno uczestnika badania jak i badacza obejmujące kwestie: miejsca realizacji wywiadu, sposobu dotarcia na miejsce realizacji wywiadu, zachowania wymaganego dystansu, noszenia osłony zakrywającej nos i usta, dezynfekcji powierzchni i wykorzystywanych materiałów (np. długopisów).

W tym miejscu należy podkreślić, że zachowanie środków ostrożności wynikających z zarządzania pandemią COVID-19 wpływać mogło zarówno na komfort uczestników (np. trudności w prowadzeniu rozmowy przy zasłoniętych ustach, dyskomfort związany z długotrwałym noszeniem osłony zakrywającej nos i usta), jak i jakość uzyskanych danych (np. trudności w odczytywaniu ekspresji emocji uczestnika badania, którego twarz jest w połowie zasłonięta, brak możliwości wykorzystania niektórych technik badawczych). Dodatkowo należy zaznaczyć, że niektórzy uczestnicy badań pomimo wcześniej wyrażonej zgody na postępowanie zgodne z zasadami wynikającymi z przyjętego sposobu zarządzania pandemią w czasie trwania sytuacji badawczej mogli nie chcieć się im podporządkowywać (np. odmowa noszenia osłony zakrywającej twarz i usta), co mogło stanowić zagrożenie dla uczestników procesu badawczego i wiązać się ze stresem.

W przypadkach, gdy z różnych względów badacze decydowali się na zmianę sposobu gromadzenia danych, rezygnując z technik wymagających bezpośrednich interakcji wybierali techniki zbliżone, opierające się o wykorzystanie nowoczesnych technologii, telefonu czy też poczty (tradycyjnej lub elektronicznej) w celu pośredniczenia kontaktu między badaczem a badanym (Lupton, 2020). Rozwiązania takie możliwe są do wdrożenia stosunkowo łatwo w przypadku niektórych technik (np. kwestionariusz ankiety można przesłać pocztą tradycyjną lub elektroniczną) w przypadku innych niemal niemożliwe (np. badania etnograficzne 
opierające się na obserwacji uczestniczącej w placówce opiekuńczej). Badacze decydujący się na zmianę sposobu gromadzenia danych musieli liczyć się ze zmianami jakie decyzja ta może pociągać za sobą dla uzyskanych wyników badań (utrata części informacji, mniejszy odsetek odpowiedzi zwrotnych, brak możliwości gromadzenia danych od uczestników wykluczonych cyfrowo, brak możliwości zastosowania określnych technik gromadzenia danych).

Badacze decydujący się na wykorzystanie technik gromadzenia danych zdalnie (w oparciu o platformy online, telefon czy pocztę) dodatkowo stawali przed wyzwaniami dotyczącymi ochrony danych osobowych, zapewnienia bezpieczeństwa zarówno uczestnikom badania jak i gromadzonym danym. Nie bez znaczenia są też możliwe utrudnienia natury technicznej (niestabilne połączenia, zagubiona korespondencja), które wpływają na komfort realizacji procesu badawczego i jakość uzyskanych danych. Warto także wspomnieć, że szczególnie istotna kwestia w badaniach z osobami starszymi czyli zbudowanie zaufania i poczucia bezpieczeństwa w sytuacji braku bezpośredniego kontaktu między badaczem a badanym może okazać się o wiele trudniejsze i niekorzystnie wpłynąć na sytuację badawczą i jakość uzyskiwanych danych (Truglio-Gallagher et al., 2006).

W tym miejscu należy także zaznaczyć, że badacze, w czasie pandemii COVID-19 byli w fazie gromadzenia danych staną przed pytaniami o to: na ile dane zostały zniekształcone przez pandemię? W jaki sposób można kontrolować to możliwe zniekształcenie, aby nie zakłócało analiz i nie zniekształciło wyników? Nie odnoszę się tu do wpływu wynikającego ze zmiany techniki gromadzenia danych (przedstawionych powyżej), ale z faktu, że dane gromadzone były w tym konkretnym momencie historycznym, co mogło wpływać na reakcje i odpowiedzi udzielane przez badanych (Babbie, 2019) także w odniesieniu do kwestii niezwiązanych bezpośrednio z pandemią COVID-19.

\section{Projekty $w$ fazie analizowania danych}

Badacze realizujący projekty, które w momencie wybuchu pandemii COVID-19 były w fazie analizowania danych znaleźli się w sytuacji, która postawiła przed nimi pytania głównie natury praktycznej : czy do analizy danych niezbędne są bezpośrednie interakcje między członkami zespołu badawczego? W jaki sposób bezpiecznie zorganizować spotkania bezpośrednie lub zdalne zespołu badawczego?

W związku z przyjętymi sposobami zarządzania pandemią wiele instytucji badawczych zamknęło swoje budynki i rekomendowało pracownikom pracę z domu, w trybie zdalnym. W przypadku wielu zespołów badawczych przekładało się to na brak możliwości organizacji spotkań bezpośrednich. Tymczasem niektóre projekty badawcze w fazie analizowania danych wymagają szczególnie intensywnych spotkań między badaczami (np. konsultacje podczas kodowania zgromadzonego materiału) a niektóre projekt mogły dodatkowo zakładać konsultacje również ze starszymi uczestnikami od których pozyskiwano dane. Przy założeniu dostępności zaplecza technicznego spotkania takie mogły być organizowane zdalnie. Wiązać się to mogło jednak z podobnymi wyzwaniami jak w przypadku gromadzenia danych w sposób zdalny: ochrona danych osobowych badaczy, uczestników badania oraz danych empirycznych. Istniejące opracowania dowodzą, że taki sposób organizowania spotkań i analizy danych może pozytywnie wpływać na proces analizy danych (Quartiroli, et al.2017).

W tym miejscu należy podkreślić, że nie wszyscy badacze dysponują takimi samymi możliwościami w ramach efektywnego realizowania pracy w systemie zdalnym, co mogło komplikować proces analizowania zgromadzonych danych. Istniejące opracowania wskazują, że w trakcie pandemii COVID-19 kobiety, które mogły być w większym stopniu obciążone jednocześnie 
pracą zawodową oraz obowiązkami rodzinnymi (zwłaszcza sprawowaniem opieki nad dziećmi podczas zamknięcia placówek edukacyjnych), dysponowały mniejszą ilością czasu i były bardziej narażone na stres (Gabster et al. 2020; Nash i Churchill, 2020).

Projekty $w$ fazie upowszechniania danych

Badacze, którzy w momencie wybuchu pandemii COVID-19 zakończyli prace analityczne i przygotowywali się do prezentacji wyników stanęli w obliczu kolejnych pytań: czy zaplanowane sposoby upubliczniania wyników wymagające bezpośrednich interakcji (udział w konferencjach, warsztatach itp.) są bezpieczne i możliwe do realizacji? W jaki sposób należy zmodyfikować sposób prezentacji wyników na potrzeby wydarzeń organizowanych w formule zdalnej?

W momencie wybuchu pandemii COVID-19 wiele konferencji, warsztatów i spotkań zmieniło formułę i realizowano je w sposób zdalny. Niektórzy z organizatorów (np. International Sociological Association) w początkowej fazie przesuwali terminy wydarzeń, jednak w obliczu natury pandemii COVID-19 (ponowny wzrost liczby zachorowań) i sposobów zarządzania nią (wzmożone restrykcje sanitarne) ostatecznie decydowali się na organizację wydarzeń w formule zdalnej. Oznacza to, że prezentacja wyników niektórych badań mogła odbyć się z opóźnieniem i/lub w zmienionej formule. Ma to znaczenie szczególnie dla młodych naukowców, którzy dzięki informacjom zwrotnym uzyskiwanym od szerokiego grona ekspertów są w stanie udoskonalać swój warsztat badawczy i rozwijać swoje umiejętności (Speirs, 2020), a w związku z wybuchem pandemii COVID-19 mogli nie mieć okazji do zdobycia informacji zwrotnych w formule i czasie, które byłyby dla nich najbardziej korzystne.

Warto też zwrócić uwagę, że prezentowanie wyników badań podczas spotkań realizowanych w formule zdalnej wymaga innego przygotowania. Brak możliwości zawiązania bezpośredniej interakcji, czy prowadzenia tzw. „rozmów kuluarowych” powoduje, że wymiana idei i opinii dla niektórych badaczy może być trudniejsza, co przekłada się na dostępność wyników ich badań (Goel i Grimpe, 2013).

\section{Zakończenie}

W tym artykule uwaga skoncentrowana została na wpływie pandemii COVID-19 na badania społeczne ze szczególnym uwzględnieniem dylematów etycznych i metodologicznych przed jakimi stają badacze realizujący projekty badawcze dotyczące starości i starzenia się. Projekty takie spotykają się z dodatkowymi wyzwaniami wynikającymi zarówno ze specyfiki badań dotyczących starości i starzenia się jak i z natury pandemii COVID-19, sposobów zarządzania nią i społecznego jej postrzegania.

Jak starałam się wykazać, szczególne znaczenie dla badań realizowanych w czasie pandemii COVID-19 ma zmienność sytuacji i niepewna przyszłość wynikające z charakteru pandemii. I choć realizacja procesu badawczego zawsze obarczona jest ryzykiem i odbywa się w jakimś stopniu w warunkach niepewności, to wybuch pandemii COVID-19 spowodował, że przed badaczami nie tylko pojawiły się zupełnie nowe dylematy natury etycznej i metodologicznej ale także część z dotychczas istniejących nabrała nowego znaczenia.

W przypadku badaczy, którzy nie zdecydowali się na przerwanie badań wiele decyzji dotyczących kwestii etycznych i metodologicznych musiało być podejmowanych ad hoc. Wiele z tych decyzji wymagało negocjacji pomiędzy najlepiej pojętym interesem potencjalnych uczestników, badaczy i instytucji finansujących badanie. Decyzje te podejmowane były w warunkach braku jasnych i jednoznacznych wytycznych. W odpowiedzi na pojawiające 
się wątpliwości i pytania badacze często posługiwali się dostępnymi kodeksami etycznymi (np. kodeks socjologa) i bazując na własnej wiedzy i doświadczeniu dostosowywali sposób działania do zmieniających się warunków. Wymagało to wykazywania się dużą elastycznością i kreatywnością przy realizacji procesu badawczego.

Dodatkową komplikacją w realizacji projektów badawczych z jaką zetknęli się badacze realizujący badania z udziałem osób starszych był szczególnie ożywiony, w związku ze sposobami zarządzania pandemią COVID-19 oraz jej społecznym postrzeganiem, ageism. Badacze starości od dawna wskazują, jak negatywne konsekwencje wynikają z ageismu (Frieske, 2003; Perek-Białas i Kocór 2005; Szukalski, 2008) i jak wciąż powszechne, nawet wśród studentów nauk społecznych, są negatywne stereotypy dotyczące osób starszych (Leszczyńska-Rajchert, 2015). W związku z tym badacze starości i starzenia się w czasach pandemii COVID-19 mogli doświadczyć dodatkowego „uwrażliwienia” i jeszcze głębszej refleksji nad znaczeniem reprezentowania w badaniach jak bardzo zróżnicowaną populację stanowią osoby starsze. Wiązać może się to także ze zwiększeniem wysiłków w opracowaniu sposobów docierania do szczególnie trudno dostępnych osób starszych (Kammerer et al., 2019).

Potencjalne długofalowe korzyści wynikające z wybuchu pandemii COVID-19 w badaniach społecznych dotyczyć mogą więc przede wszystkim zwiększonej refleksyjności i kreatywności badaczy ${ }^{1}$ (Sosa, 2020). Dodatkowym pozytywnym aspektem może być „oswojenie” zdalnych technik podczas gromadzenia danych, ich analizy i prezentacji wyników badań. Jednak w kontekście badań nad starością i starzeniem się w Polsce należy zwrócić uwagę na znaczne wykluczenie cyfrowe osób starszych (Batorski, 2009). W celu wykorzystania technik komputerowych na etapie gromadzenia danych konieczna byłaby eliminacja barier technicznych oraz dalszy rozwój edukacyjnych w zakresie technik komputerowych (Halicka i Halicki, 2017). Należy także zaznaczyć, że kolejną możliwą korzyścią jest możliwe poszerzenie pola badawczego nauk społecznych, w tym także badań dotyczących wpływu pandemii COVID-19 na różne aspekty przeżywania starości.

Niniejsze opracowanie nie miało na celu prezentowania uniwersalnych zasad realizowania badań w czasie pandemii COVID-19. Ze względu na charakter samej pandemii byłby to cel nieosiągalny. Prezentując jednak pytania natury etycznej i metodologicznej jakie wybuch pandemii COVID-19 mógł stawiać przed badaczami realizującymi projekty badawcze dotyczące starości i starzenia się, chciałam zwrócić uwagę na możliwe sposoby reagowania na bezprecedensową sytuację i wskazać możliwe skutki zaburzenia przyjętego sposobu realizacji badań.

Wybuch pandemii COVID-19 stawia wiele pytań przed badaczami starości i starzenia się. Część z nich zaprezentowałam w niniejszym opracowaniu. Należy mieć nadzieję, że kolejne opracowania dokumentujące strategie podejmowane w czasach pandemii COVID-19 przez badaczy starości i starzenia się pozwolą na pogłębienie refleksji nad stosowaną metodologią i dalszym rozwojem badań oraz opracowanie praktycznych wskazówek jak radzić sobie z pojawiającymi się wyzwaniami. Szczególnie interesujące i użyteczne może okazać się analizowanie wpływu pandemii COVID-19 na badania międzynarodowe, gdzie interakcje czynników dotyczących natury pandemii, sposobów zarzadzania nią i jej społecznego postrzegania zyskają kontekst międzynarodowy i międzykulturowy stwarzając nowe wyzwania i nowe możliwości dla badaczy. Otwarte pozostaje także pytanie na ile zmiany wywołane pandemią COVID-19 na sposób myślenia o realizacji badań społecznych, w tym badań z osobami starszymi okażą się trwałe.

Przykładem takiej kreatywności może być konkurs na pamiętnik Pandemii (IFIS PAN, 2020), którego autorzy wykorzystali wybuch pandemii COVID-19 do realizacji „wyjątkowych” badań. 


\section{Literatura}

Augustyniak, P., Ciesiołkiewicz, K., Fandrejewska-Tomczyk, A., Gąciarz, B., .. \& Wygnański, K. (2020). Alert Społeczny 7. Pobrane z: https://oees.pl/alerty-eksperckie/ [dostęp: 26.11.2020]

Ayalon, L., Chasteen, A., Diehl, M., Levy, B., Neupert, S. D., Rothermund, K., .. \& Wahl, H. W. (2020). Aging in times of the COVID-19 pandemic: Avoiding ageism and fostering intergenerational solidarity. The Journals of Gerontology: Series B, gbaa051, https://doi.org/10.1093/geronb/gbaa051

Babbie, E. R. (2019). Badania społeczne w praktyce. Wydawnictwo Naukowe PWN.

Batorski, D. (2009). Wykluczenie cyfrowe w Polsce. Studia Biura Analiz Sejmowych, 3(19), $223-249$.

Błocki Z. (2020). NCN w czasie pandemii. Forum Akademickie, 5/2020,7. Pobrane z: https://miesiecznik.forumakademickie.pl/czasopisma/fa-05-2020/?download=pdf\&mid=2514 [dostęp: 15.10.2020]

BSG, 2020: COVID-19: BGS statement on research for older people during the COVID-19 pandemic. Pobrany z: https:// www.bgs.org.uk/resources/covid-19-bgs-statement-on-research-for-older-people-during-the-covid19-pandemic [dostęp:10.10.2020]

Frieske, K.W.,(2003) Marginalność społeczna, w: Encyklopedia socjologii, t. II, (s. 168), Oficyna Wydawnicza, Warszawa.

Gabster, B. P., van Daalen, K., Dhatt, R., \& Barry, M. (2020). Challenges for the female academic during the COVID19 pandemic. The Lancet, 395(10242), 1968-1970.

Goel, R.K., Grimpe, C.(2013) Active versus passive academic networking: evidence from micro-level data. Journal of Technology Transfer 38, 116-134. https://doi.org/10.1007/s10961-011-9236-5.

Halicka, M., \& Halicki, J. (2017). Starzenie się i starość w badaniach i praktyce edukacyjnej-wybrane aspekty. Pedagogika Społeczna, 2(64), 151-164.

Hausner, J. (2007). Ekonomia społeczna jako sektor gospodarki. Ekonomia Społeczna, 1, 9-14.

ICSG (2020), Combatting exclusions and ageism for older people during the COVID-19 Pandemic. Pobrane z: https:// icsg.ie/combatting-exclusions-and-ageism-for-older-people-during-the-covid-19-pandemic [dostęp: 10.10.2020]

IFiS PAN, Instytut Kultury Polskiej Uniwersytetu Warszawskiego, Instytut Socjologii Uniwersytetu Warszawskiego (2020). Pamiętniki Pandemii. Pobrane z: https://pamietnikipandemii.pl/ [dostęp: 26.11.2010]

Jacelon, C. S. (2007). Older adults' participation in research. Nurse Researcher, 14(4).

Jowett, A. (2020). Carrying out qualitative research under lockdown-practical and ethical considerations. Impact of Social Sciences Blog. Pobrane z: https://blogs.Ise.ac.uk/impactofsocialsciences/2020/04/20/carrying-out-qualitative-research-under-lockdown-practical-and-ethical-considerations [dostęp:10.10.2020]

Kammerer, K., Falk, K., Herzog, A., \& Fuchs, J. (2019). How to reach 'hard-to-reach'older people for research: The TIBaR model of recruitment. Survey Methods: Insights from the Field. Pobrane z: https://surveyinsights. org/?p=11822DOl:10.13094/SMIF-2019-00012 [dostęp: 10.10.2020]

Leszczyńska-Rejchert, A. M. (2015). „Wyjątkowi” seniorzy w percepcji studentów. Acta Universitatis Lodziensis. Folia Oeconomica, 4(315), 91-107.

Li, L. Q., Huang, T., Wang, Y. Q., Wang, Z. P., Liang, Y., Huang, T. B., .. \& Wang, Y. (2020). COVID-19 patients' clinical characteristics, discharge rate, and fatality rate of meta-analysis. Journal of medical virology, 92(6), 577-583.

Lupton, D. (red.) (2020) Doing fieldwork in a pandemic (crowd-sourced document). Pobrane z: https://docs.google. com/document/d/1clGjGABB2h2qbduTgfaribHmog9B6P0NvMgVuiHZCl8/edit?ts=5e88ae0a\#

Nash, M., Churchill, B. (2020) 'Caring During COVID-19: A Gendered Analysis of Australian University Responses to Managing Remote Working and Caring Responsibilities', Feminist Frontiers/Gender, Work and Organization 2 June, URL (consulted 1 May 2020): https://onlinelibrary.wiley.com/doi/abs/10.1111/gwao.12484

Omary, M. B., Eswaraka, J., Kimball, S. D., Moghe, P. V., Panettieri, R. A., \& Scotto, K. W. (2020). The COVID-19 pandemic and research shutdown: staying safe and productive. The Journal of Clinical Investigation, 130(6).

Perek-Białas J., Kocór M.(2005), Inne, gorsze traktowanie osób starszych w obszarze partycypacji społecznej?, W: Tokarz B. (red.), STOP dyskryminacji ze względu na wiek, s. 62-71, Akademia Rozwoju Filantropii w Polsce, Warszawa

Perek-Białas, J. (2013). Starzenie się ludności - wyzwanie dla podmiotów ekonomii społecznej?. Ekonomia Społeczna, 2, 70-81.

Previtali, F., Allen. L \& Varlamova, M. (2020) Not Only Virus Spread: The Diffusion of Ageism during the Outbreak of COVID-19, Journal of Aging \& Social Policy, 32:4-5, 506-514, DOI: 10.1080/08959420.2020.1772002

PTS (2012), Kodeks etyki socjologa, pobrane z: https://pts.org.pl/wp-content/uploads/2016/04/kodeks.pdf [dostęp: 10.10.2020]

Rahman, A., \& Jahan, Y. (2020). Defining a 'Risk Group'and Ageism in the Era of COVID-19. Journal of Loss and Trauma, 1-4. 
Rozporządzenie Ministra Zdrowia z dnia 13 marca 2020 r. w sprawie ogłoszenia na obszarze Rzeczypospolitej Polskiej stanu zagrożenia epidemicznego. (Dz.U. z 2020 r. poz. 433)

Sosa, R. (2020). Creative design research methodologies W: H Kara, S M Khoo (red.). Researching in the Age of COVID-19 Volume III: Creativity and Ethics, Policy Press.

Speirs, V. Reflections on the upsurge of virtual cancer conferences during the COVID-19 pandemic. Britsh Journal of Cancer, 123, 698-699 (2020). https://doi.org/10.1038/s41416-020-1000-x

Szukalski, P. (2008). Ageizm-dyskryminacja ze względu na wiek. Wydawnictwo Uniwersytetu Łódzkiego.

Tisdell, C. A. (2020). Economic, social and political issues raised by the COVID-19 pandemic. Economic Analysis and Policy, 68, 17-28

Truog, R. D., Mitchell, C., \& Daley, G. Q. (2020). The toughest triage-allocating ventilators in a pandemic. New England Journal of Medicine, 382(21), 1973-1975.

Truglio-Gallagher, M., Gallagher, L. P., Sosanya, K., \& Hendrickson-Slack, M. (2006). Building trust between the older adults and researchers in qualitative inquiry. Nurse Researcher, 13(3).

Weiss, D., \& Lang, F. R. (2012). "They" are old but "I" feel younger: Age-group dissociation as a self-protective strategy in old age. Psychology and Aging, 27(1), 153-163. https://doi.org/10.1037/a0024887

Winship, C., \& Mare, R. D. (1992). Models for sample selection bias. Annual Review of Sociology, 18(1), 327-350

Quartiroli, A., Knight, S. M., Etzel, E. F., \& Monaghan, M. (2017). Using Skype to facilitate team-based qualitative research, including the process of data analysis. International Journal of Social Research Methodology, 20(6), 659-666.

\section{The impact of the COVID-19 pandemic on social research of age and ageing}

Summary: In the COVID-19 pandemic, social researcher faced unprecedented constraints as most of their data collection techniques base on direct human interaction. As a result, many researchers involved in ageing research are now faced with ethical and methodological challenges. The aim of this article is to provide a subjective reflection on the ethical and methodological aspects of conducting social research on old age and ageing during the COVID-19 pandemic. I identify the factors influencing social research during the COVID-19 pandemic and then present ethical and methodological questions that may have arisen at each stage of the research process. There are no universal strategies nor solutions for of conducting social research on old age and ageing during the COVID-19 pandemic.

Keywords: older adults; social research; COVID-19; methodology, ethics

JEL codes: 114,118

\section{Informacje o autorce}

\section{Anna Urbaniak, dr}

\section{ORCID: 0000-0002-9183-2042}

Institut für Soziologie

Universität Wien

Rooseveltplatz 2

1090 Wien

e-mail: anna.urbaniak@univie.ac.at

Autorka pragnie podziękować recenzentom oraz następującym osobom za dyskusje i wskazówki doskonalące tekst: prof. dr hab. Marek Ćwiklicki - Uniwersytet Ekonomiczny w Krakowie, dr Lucie Galcanova Batista Masaryk University, dr Anna Wanka-Goethe-Universität Frankfurt. 


\section{Prawa autorskie i licencja / Copyright and License}

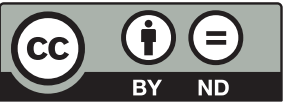

Publikacja na licencji Creative Commons Uznanie autorstwa Użycie niekomercyjne - Bez utworów zależnych 4.0 Międzynarodowe (CC BY-ND 4.0) http://creativecommons.org/licenses/by-nc-nd/4.0/deed/pl

This work is published under the terms of the Creative Commons

Attribution - NoDerivetives International (CC BY-ND 4.0) License http://creativecommons.org/licenses/by-nc-nd/4.0

Wydane przez Uniwersytet Ekonomiczny w Krakowie. Małopolska Szkoła Administracji Publicznej

Published by Cracow University of Economics - Krakow, Poland. Małopolska School of Public Administration of the Cracow University of Economics 